\title{
West Nile virus infection presenting as acute flaccid paralysis in an HIV-infected patient A case report and review of the literature
}

Mauro Torno, MD; Michael Vollmer, MD; and C. Keith Beck, MD

\begin{abstract}
We describe a case of West Nile virus (WNV) infection in an HIVinfected patient who presented with an isolated flaccid monoparesis of the right upper extremity. To our knowledge, this is the first reported case of flaccid paralysis caused by WNV infection in an HIVinfected patient. We then review the medical literature on WNV infection occurring among patients who are infected with HIV. Unlike most of the cases reported in the literature, our patient had partial recovery of his neurologic deficits.
\end{abstract}

The incidence of West Nile virus (WNV) infection, a mosquitoborne disease, is highest in the summer months in temperate areas such as North America. ${ }^{1-3}$ In other regions of the world, yearround transmission is common. The majority of reported infections occur in the elderly (age $>50),{ }^{4,5}$ whereas subclinical infections are fairly evenly distributed, based upon serosurvey results. Approximately $80 \%$ of WNV infections are asymptomatic,,$^{2,4,6}$ and the remaining $20 \%$ present with symptoms of West Nile fever, which may include fever, headache, fatigue, and skin rash. ${ }^{4}$ $\mathrm{CNS}$ involvement in $\mathrm{WNV}$ infection is uncommon $(<1 \%){ }^{6,7} \mathrm{WNV}$ CNS disease can be categorized into three broad, but frequently overlapping clinical syndromes: encephalitis, meningitis, and acute flaccid paralysis (AFP). The most common presentation of neuroinvasive WNV disease is encephalitis (60 to $75 \%$ ) and/or meningitis (25\%). ${ }^{4,8}$ AFP is a much less common CNS presentation of WNV infection.

WNV infection has been described in association with various types and degrees of immunosuppressive conditions. ${ }^{6,8,9}$ To date, however, there have only been four case reports of WNV infection occurring among patients infected with HIV. ${ }^{10-12}$ We describe a case of WNV infection in an HIV-infected patient who presented with an isolated flaccid monoparesis of the right upper extremity. To our knowledge, this is the first reported case of AFP caused by WNV infection in an HIV-infected patient. We also review the medical literature on WNV infections that present acutely as flaccid paralysis.

Case report. A 47-year-old HIV-infected Hispanic man from Los Angeles, CA, presented to the clinic with a 3-day history of progressive weakness of the right upper extremity. He also reported headache, neck pain, fever, and malaise. He had no history of opportunistic infections or malignancies in the past and was antiretroviral therapy naive. His CD4 count was 324 cells/ $\mu \mathrm{L}$, and his
HIV viral load was 25,012 copies/ $\mathrm{mL}$. There was no history of recent travel or vaccinations. $\mathrm{He}$ was treated for syphilis of unknown duration in 1999; his rapid plasma regain titer remained serofast at 1:4 dilution through the years. On physical examination, he was febrile to $100{ }^{\circ} \mathrm{F}$ with normal blood pressure and heart and respiratory rates. The rest of the physical examination was within normal limits. Neurologic examination revealed an alert man oriented to time, place and person. There were no cranial nerve deficits. He had an isolated right upper extremity proximal muscle weakness (0/5) and was areflexic in the same muscles. There were no sensory deficits noted. He was able to do the finger-to-nose test on the left and was able to do the heel-to-shin-to-toe test bilaterally. Babinski signs were absent bilaterally.

CT of the head without contrast material was normal. The opening pressure with lumbar puncture (LP) was $17 \mathrm{~mm} \mathrm{Hg}$. CSF analysis showed lymphocytic pleocytosis with 184 white cells/ $\mathrm{mm}^{3}$, a protein level of $75 \mathrm{mg} / \mathrm{dL}$, and a glucose level of $60 \mathrm{mg} / \mathrm{dL}$. CSF Gram, acid-fast bacilli, potassium hydroxide, and India ink stains were negative. The patient

From the Department of Medicine, David Geffen School of Medicine at University of California at Los Angeles (UCLA) and Harbor-UCLA Medical Center, Torrance, CA.

Disclosure: The authors report no conflicts of interest.

Received May 31, 2006. Accepted in final form October 19, 2006

Address correspondence and reprint requests to Dr. M.S. Torno, Early Intervention Program, Long Beach Health Department, 2525 Grand Ave., Suite 106 , Long Beach, CA 90815; e-mail: Mauro_Torno@longbeach.gov 
was given antibacterial (ceftriaxone), antifungal (fluconazole), and antiviral (acyclovir) treatment; because of the history of syphilis infection, IV penicillin (2 million U every 4 hours) was also started. MRI of the brain and cervical spine was normal. Headache and fever were resolved by the 3 rd hospital day.

On the 7th hospital day, the patient developed a right peripheral seventh cranial nerve palsy. The LP again showed lymphocytic pleocytosis. Repeat CT scan of the head was also normal. At this time, the results came back negative for the following tests: CSF Venereal Disease Laboratory, CSF and serum cryptococcal antigen, and serum coccidiodomycosis antibodies. Bacterial cultures of blood and CSF did not grow any organisms.

On the 13th hospital day, WNV ELISA results came back positive for WNV neuroinvasive disease. The CSF WNV-specific IgM was $5.44(<0.90$ normal $)$ and the CSF WNV-specific IgG was 2.21 $(<1.30$ normal). The serum plaque reduction neutralization test (PRNT) was confirmatory for acute WNV infection. The CSF arbovirus antibody panel was negative for eastern and western equine, St. Louis, and California encephalitis viruses. With stable neurologic deficits, the patient was discharged from the hospital the next day. Acute and convalescent sera showed a fourfold rise in WNV antibody titer.

Discussion. WNV CNS infection commonly presents as encephalitis or meningitis. AFP of the limbs, similar to poliomyelitis, is an uncommon manifestation of WNV infection. Although AFP may occur in isolation, it is usually accompanied by encephalitis and/or meningitis. Especially in the summer months, it is important to consider the diagnosis of WNV CNS infection when a patient presents with flaccid paralysis.

Flaccid paralysis resulting from WNV infection is well described in the medical litera- ture. ${ }^{6,9}$ The data are derived largely from patients who are not known to have accompanying HIV infection. In one series, ${ }^{9}$ the limb weakness was described as markedly asymmetric, progressing in minutes or hours to frank paralysis, with minimal or no fever $^{4}$ or viral prodrome. The paralysis is likely caused by damage to the anterior horn cells of the spinal cord, either by direct viral invasion or as a reaction to an immunologic process triggered by WNV. ${ }^{6,8,13}$ As seen in poliomyelitis, this denervation causes loss of motor function at that level with minimal or no sensory involvement. ${ }^{8,13}$ Limb weakness is usually accompanied by signs and symptoms of encephalitis and/or meningitis; however, limb weakness may also occur in isolation. . $^{8,9,13}$ Patients who were age $\leq 50$ were more likely to present with monoparesis (as in our case), whereas patients who were age $\geq 65$ either had paraparesis or quadriparesis. ${ }^{3}$ The assumption is that older patients tended to have more diffuse involvement of the anterior horn cells by WNV infection, hence more widespread limb involvement. ${ }^{3}$ Acute respiratory failure requiring mechanical ventilation has been described in the setting of AFP. ${ }^{6}$ Autonomic involvement, manifested as bowel and bladder dysfunction, may also be present. ${ }^{3,6,8,13}$ Cranial nerve palsies, usually peripheral facial nerve palsy, ${ }^{2,9}$ have been reported to evolve during the time of hospitalization ${ }^{2}$ (as seen in our patient).

The majority of the patients with WNV CNS infection present with CSF pleocytosis and elevated CSF protein levels. ${ }^{2,4,6} \mathrm{CSF}$ glucose is usually normal. ${ }^{2,4}$ Brain MRI findings may be entirely nor$\mathrm{mal}^{6}$ or show hyperintense T2 and fluid-attenuated inversion recovery signals, with accompanying diffusion abnormalities or gadolinium enhancement., ${ }^{2,13}$ Spine MRI findings may be normal or show evidence of meningitis, myelitis, or polyradiculitis. ${ }^{2,6,13}$ Motor nerve conduction studies typically show severely reduced amplitudes of compound muscle action potentials in the affected limbs, whereas nerve conduction velocities are usually intact. ${ }^{2,9}$

Serum or CSF collected after the onset of illness is diagnostic of WNV infection if meeting defined criteria. Because IgM antibody does not normally cross the blood-brain barrier, detection of IgM antibody to WNV in the CSF strongly suggests WNV CNS infection. ${ }^{4}$ A fourfold or greater increase in WNV-specific neutralizing antibody titer between acute ( 0 to 8 days after the onset of the illness) and convalescent (14 to 21 days after the acute specimen) phase serum specimens also confirms WNV infection. ${ }^{4}$ There is extensive serologic crossreactivity among the flaviviruses. ${ }^{1,4}$ State-run laboratories have the capability to perform the PRNT on serum samples that are positive for WNV infection. The PRNT is specific for acute WNV infection. ${ }^{4}$

Flaccid paralysis caused by WNV infection may easily be confused with Guillain-Barré syndrome (GBS) or stroke. Unlike WNV flaccid paralysis, however, GBS generally produces symmetric, ascending limb weakness with accompanying sensory changes. ${ }^{13} \mathrm{CSF}$ pleocytosis is usually absent in GBS. ${ }^{13}$ Strokes typically produce distinct findings on CT scan or MRI, which, in some situations, evolve clinically and radiologically over time. The paralysis here is usually spastic, not flaccid. In an HIV-infected patient, the differential diagnosis of AFP, especially when combined with fever, headaches, and any degree of cognitive impairment, becomes even more complex. Cryptococcosis, coccidioidomycosis, histoplasmosis, tuberculosis, lymphoma, neurosyphilis, and HIV myelopathy should all be considered when an HIV-infected individual presents with fever, headache, and paralysis. Appropriate serologic testing and radiologic imaging should guide subsequent workup and therapy.

Treatment of WNV infection is supportive. Mortality rate is in- 
creased in those with encephalitis and among the elderly $\geq 65$ years. ${ }^{3,6}$ The rehabilitation potential among WNV patients who had AFP is poor. In one study, ${ }^{6}$ neurologic impairments persisted among all survivors. In other case series, ${ }^{2,14}$ limb weakness was still present at 6- to 8-month followup, with continuing problems in the performance of activities of daily living such as grooming, housekeeping, and mobility. ${ }^{2}$ Eight months after follow-up, our patient had fully recovered from the right seventh peripheral cranial nerve palsy. He had also regained some of the strength $(2 / 5$ from $0 / 5$ baseline) back from the proximal muscle groups of the right upper extremity. Large, prospective studies with lengthier time to follow-up are needed to characterize the natural history of this condition in both the general and the HIV-infected populations. $^{14}$
This article, it is hoped, will help raise awareness of the possibility of AFP in WNV infection. Early diagnosis of WNV neuroinvasive disease should help 1) promote more efficient surveillance and containment of WNV infection 2) speed referral to local health departments, and 3) contribute to better use and allocation of hospital resources.

\section{References}

1. Centers for Disease Control and Prevention, Division of Vector-Borne Infectious Diseases. West Nile Virus: Epidemiologic Information for Clinicians. Available at http://www.cdc.gov/ncidod/dvbid/westnile/ clinicians/epi.htm. Accessed 13 September 2005.

2. Jeha LE, Sila CA, Lederman RL, et al. West Nile virus infection: a new acute paralytic illness. Neurology 2003;61:55-59.

3. Emig M, Apple DJ. Severe West Nile virus disease in healthy adults. Clin Infect Dis 2004;38:289-292.

4. Centers for Disease Control and Prevention, Division of Vector-Borne Infectious Diseases. West Nile Virus: Clinical Description. Available at http://www.cdc.gov/ncidod/ $\mathrm{dvbid} /$ westnile/clinicians/clindesc.htm. Accessed 13 September 2005.

5. Nash D, Mostashari F, Fine A, et al. The outbreak of West Nile virus infection in the
New York City area in 1999. N Engl J Med 2001;344:1807-1814.

6. Saad M, Youssef S, Kirschke D. Acute flaccid paralysis: the spectrum of a newly recognized complication of West Nile virus infection. J Infect 2005 Aug;51:120-7. Epub 2004 Nov 6.

7. Dean JL, Palermo BJ. West Nile virus encephalitis. Curr Infect Dis Rep 2005;7:292296.

8. Sejvar JJ, Haddad MB, Tierney BC. Neurologic manifestations and outcome of West Nile virus infection. JAMA 2003;290:511515.

9. Li J, Loeb JA, Shy ME. Asymmetric flaccid paralysis: a neuromuscular presentation of WNV infection. Ann Neurol 2003;53:703710.

10. Szilak I, Minamoto GY. West Nile viral encephalitis in an HIV-positive woman in New York. N Engl J Med 2000;342:59-60.

11. Gaurner J, Shieh WJ, Hunter S, et al. Clinicopathologic study and laboratory diagnosis of 23 cases with West Nile virus encephalomyelitis. Hum Pathol 2004;35: 983-990.

12. Gyure KA. West Nile virus encephalomyelitis in the setting of human immunodeficiency virus (HIV) infection. J Neuropathol Exp Neurol 2005;64:446.

13. Sejvar JJ, Bode AV, Marfin AA. West Nile virus-associated flaccid paralysis. Emerg Infect Dis 2005;11:1021-1027.

14. Marciniak C, Sorosky S, Hynes C. Acute flaccid paralysis associated with West Nile virus: motor and functional improvement in 4 patients. Arch Phys Med Rehabil 2004;85: 1933-1938. 


\section{Neurology}

\section{West Nile virus infection presenting as acute flaccid paralysis in an $\mathrm{HIV}$-infected patient: A case report and review of the literature \\ Mauro Torno, Michael Vollmer and C. Keith Beck \\ Neurology 2007;68;E5-E7 \\ DOI 10.1212/01.wnl.0000253223.07720.bb}

This information is current as of February 12, 2007

Updated Information \& Services

References

Subspecialty Collections

Permissions \& Licensing

Reprints including high resolution figures, can be found at: http://n.neurology.org/content/68/7/E5.full

This article cites 11 articles, 1 of which you can access for free at: http://n.neurology.org/content/68/7/E5.full\#ref-list-1

This article, along with others on similar topics, appears in the following collection(s):

Amyotrophic lateral sclerosis

http://n.neurology.org/cgi/collection/amyotrophic_lateral_sclerosis_ Viral infections

http://n.neurology.org/cgi/collection/viral_infections

Information about reproducing this article in parts (figures,tables) or in its entirety can be found online at:

http://www.neurology.org/about/about_the_journal\#permissions

Information about ordering reprints can be found online:

http://n.neurology.org/subscribers/advertise

Neurology ${ }^{\circledR}$ is the official journal of the American Academy of Neurology. Published continuously since 1951, it is now a weekly with 48 issues per year. Copyright . All rights reserved. Print ISSN: 0028-3878. Online ISSN: 1526-632X.

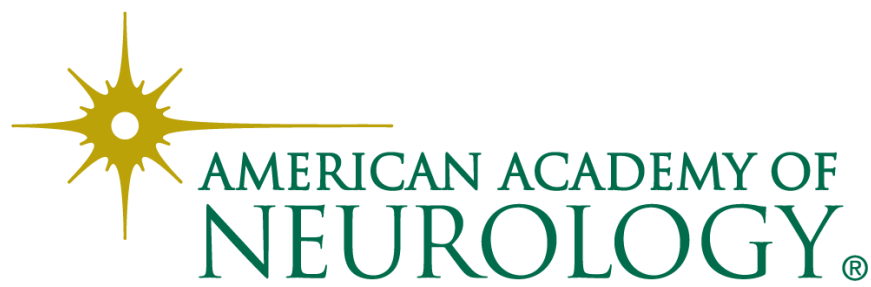

